\title{
Eagleton, Terry, Materialism ${ }^{1}$
}

\section{Jovito V. Cariño}

$\mathrm{T}$ lerry Eagleton makes a bold claim on the basis of which he lodges an updated take on materialism, the very title of his recent work. There seems to be, as he perceives, a widespread marginalization of the body as an interpretive text not only within the academe but in almost all domains of cultural studies. What he proposes to do in this book is to mend the waning, or in some cases, misplaced interest on the body and reinstate it in its universal stature. Apparently, Eagleton is not satisfied bwith the way the body is construed as a construct by some genres of intellectual discourse, or caricatured by popular culture, the mainstream as well as the social media, and hence, his attempt to recover it as a "rudimentary" entity. He traces the restoration of interest on the body to the writings of Michel Foucault in the 1960s which, per his account, reconnects political theory with the intricacies and sensibilities of the flesh.

Materialism is a well-pedigreed concept. As shown by Marx in his doctoral dissertation, Democritus and Epicurus had long propounded the idea before it even became a byword among the intellectuals and natural philosophers of the Enlightenment. For its advocates, old and new, Eagleton contends that materialism stands for the repudiation of "priestcraft and superstition." This is not to say, however, that thinkers of the modern period are of one mind on their materialist claims. Newton and Darwin are both scientists, but they adhere to starkly different materialist tenets. The same is true for Spinoza and Engels, who both think of matter as all there is, but would argue in separate ways what makes it such. The debates, as Eagleton would have them, swing from equating materialism with humanism (Spinoza), to affirming deism thru matter (Newton), to levelling anything human to the immanence of material reality (Darwin and Engels), to recognizing human agents as correlates of his material world (Freud and Marx). A great contribution to these debates are, of course, the theories of dialectical materialism and historical materialism; and the Marxist ontology and philosophy of history, respectively espoused by Marx and Engels, albeit

${ }^{1}$ New Haven: Yale University Press, 2016, 192 pp.

(c) 2017 Jovito V. Cariño

https://www.kritike.org/journal/issue 21/carino december2017.pdf

ISSN 1908-7330

(cc) $\mathrm{BY}-\mathrm{NC}-\mathrm{ND}$ 
in recent years, more and more contenders have come to challenge the canonical stature of these Marxist materialist doctrines. Among these challengers, Eagleton names vitalism, a strand of materialism identified with figures like Schelling, Nietzsche, and Deleuze. It is the same emergent philosophic thought that has gained traction in the writings of the likes of Zizek, and the exponents of the so-called New Materialism. However, far from yielding matter its rightful place, these conceptual innovations produce contrary results. In its wake, materialist discourse is left in utter disarray and matter itself is reduced into a sort of "materiality without substance."

Eagleton is all for rehabilitating appreciation of material existence, but he would have none of the romantic, post-structuralist stance which denigrates humanity to elevate the material constitution of the world it inhabits. In his usual witty, yet insightful remark - an abundance of which makes his book an engaging and adventurous read - he affirms that: "Matter may be alive, but it is not alive in the sense that human beings are. It cannot despair, embezzle, murder or get married. The moon may be in some sense a living being, but it cannot prefer Schoenberg to Stravinsky." As far as he is concerned, when it comes to matter, neither idealist humanism (which sets humanity above matter) nor mechanical materialism (which upholds matter above humanity) is our only choice. Vitalism counts itself as an alternative, but its disavowal of human agency and its notion of matter as a super fluid reality, argues Eagleton, seems to work against its cause. There is no way for vitalism to keep its materialist provenance while it pushes to the margins, "the peculiar form of materiality," which characterizes the human person. In doing so, it forfeits its claim not only to materialism, but moreso to radicalism. By way of example, Eagleton singles out Deleuze as the best representative of this "cosmic vitalism" which considers the body as force and for which any

form of constraint is deemed as negative. In taking matter as flux or a field of virtualities, resistant to any barrier or impediment, Deleuze unwittingly reproduces a kind of "Romantic-libertarian philosophy" which underwrites the same market ideology which he vehemently rejects.

Besides vitalism, other varieties of materialism include: material culturalism, which inquires into the material contexts of art (Raymond Williams); semantic materialism, which takes meaning as a function of material sign and, as in Marx, recognizes the public character of language (Ludwig Wittgenstein); somatic materialism, which takes the body as the ground and origin of thought (Jean Luc Nancy), a vessel of both ascetic and aesthetic experiences (St. Paul), or the seedbed of the unconscious (Sigmund Freud); and speculative materialism, which insists on the infinity of thought and the corollary contingency of everything, man and God included (Quentin Meillasoux).

(c) 2017 Jovito V. Cariño

https://www.kritike.org/journal/issue 21/carino december2017.pdf

ISSN 1908-7330

(c) $)$ BY-NC-ND 
This cacophony of paradigms simply shows, as Eagleton presents, the extent and complexity of the problem that materialism represents. To restrict materialism, therefore, to mind-body dichotomy, to phenomenology, or to quantum physics, is to look at this problem with a myopic eye. In fact, the urgent and more salient aspects of the questions that materialism poses find their best expression neither in scientific nor philosophic treatises alone; one may also have enough of it, says Eagleton, in commonplace materialism by which he means excessive regard to material goods. It is the kind of materialism that the once popular song of Madonna or the recent one of Jessie $\mathrm{J}$ reminds us. People who are materialistic in this sense consider matter not as the opposite of the spiritual, but the very impetus as to why they seek out the respite provided by different spiritual outlets no matter how phony. As Eagleton remarks: "People who have a surplus of material goods are likely to resort to bogus forms of spirituality as a much-needed refuge from them. A gullible belief in wood nymphs, magic crystals, Theosophy or alien spacecraft is simply the flipside of their worldliness." Moreover, there is this materialism in a broad sense which Eagleton describes as "materialist imagination." Apparently, this one refers to the mindfulness akin to a poet's eye that wonders about and admires "the flow and texture of material things." This tapestry of rival materialist theories serves as the background of Eagleton's theoretical experiment aimed at confronting materialism's contemporary conceptual predicament. His project is to devise a theory closely linked with historical materialism, but it is not exactly, as he claimed, "identical with it."

Rather than labeling or defining the project he has in mind, Eagleton tours the reader into the intricate dimensions of his exploration in a manner that evokes simultaneous insight and delight. One cannot help but be won over by his almost seamless prose through which he navigates his way from Wittgenstein to Merleau-Ponty, to Aquinas, to Marx, and to Freud, among others, to argue for the reinstatement of the perception of the body as a specific entity much to the anticipated consternation of the vitalists and various post-modern cultural theorists. Eagleton emphasizes that the human body is "matter of a highly specific kind" and such specificity is what underwrites his/her identity as a human person. Taken from Aristotle, Wittgenstein, and Aquinas, he takes the human body as ontologically united with the soul, thus making it "inherently active, creative, communicative, relational, self-expressive, self-realising, world-transforming and selftranscendent (which is to say, historical)." The soul, conventionally designated as form of the body, is a functional term which, Eagleton explains, is employed mainly to distinguish not so much soul from the body, but the human body from other materially-constituted objects like tables and rubber tires. As he states more pointedly: "You can see someone's soul just as you 
can see their grief or rage. In fact, to see their grief or rage is to see their soul." It is enlightening as it is surprising how a Marxist and non-religious thinker like Eagleton could mine from Aquinas, a materialism that sits well with the worldview of the differently-minded thinkers like Marx, Wittgenstein, Merleau-Ponty, and Joyce. His discussion of the materialist aspect of Aquinas' philosophical anthropology and theology of creation endows the latter with a currency that casts him in a radically new light. To quote Eagleton: "Whatever our differences from the beasts, our own forms of reasoning are in Aquinas' view deeply embedded in our animal nature, which is one reason why he is by no means the arid rationalist that some have taken him to be."

The reiteration of the soul or the specificity of the human body is crucial for Eagleton's updating of Marx's historical materialism. As the book progresses, it becomes clearer that such updating requires a balancing act between Marx's priority of human historicity (that is, human mutability and creativity) and that which is essentially unchangeable in the human person. In referring to the latter, Eagleton, at times, would also use the terms "necessity," "objectivity," or "Nature." One may accuse him of revisionism but one definitely cannot discount the merit of his arguments taken as they are from contemporary perspectives on materialism and Marx's texts themselves. Eagleton points out: "The belief that certain aspects of humanity remain more or less constant is not among the most widely advertised features of Marx's thought. Instead, he is usually seen (not least by his disciples) as a full-blooded historicist - as one for whom all phenomena are historical all the way down, and thus both changing and changeable. This, gratifyingly, is not the case ... Marx is indeed a historicist, but not a fullblooded one."

As Eagleton argues, there in enough evidence in Marx to underscore his belief on the fundamentality of Nature over history. Case in point is Marx's characterization of the human person as a species-being which alone allows him/her to act out his historicity. What Eagleton hopes to articulate, nonetheless, is not so much a romantic valorization of Nature, but a revival of the often-neglected insight from Marx concerning the intersecting dynamics between Nature and history. The convergence between the two can assume a variety of forms. One of them is labor, another is sexual act, and yet another, is art. While we have not had a short supply of these, increasingly, Eagleton observes, they have become for us abstract experiences. By indulging in these abstract engagements (which, considerably, is the only thing that capitalism can offer), the human body is "stripped of its substance." It turns out then that the enemy of materiality is not so much spirituality, but materialism in the vulgar sense of the word, that is, in the sense of an excessive propensity to treat material goods as mere objects of consumption.

(c) 2017 Jovito V. Cariño

https://www.kritike.org/journal/issue 21/carino december2017.pdf

ISSN 1908-7330

(cc) BY-NC-ND 
Marx's celebration of the body, his somatic materialism, is deemed by Eagleton as comparable to Nietzsche's, despite the glaring incompatibilities between the two thinkers, particularly in their views on politics and society. What prevents Eagleton from endorsing Nietzsche's brand of materialism is the latter's almost metaphysical glorification of willto-power as the ultimate human value. As a moral and political concept, willto-power is bound to be exclusionary and outright discriminatory, the very traits which militate against Marx's materialist humanism. A body or experience does not become greater or lesser just because it belongs to someone from a different class, race, color, or religion. Paraphrasing Wittgenstein's notion of language and its rootedness in forms of life and bodily behavior, Eagleton writes towards the end of his book: "We have a range of natural, instinctive responses to others (fear, pity, disgust, compassion and so on) which eventually enter into our moral and political language-games but which are in themselves prior to interpretation. And these responses, belonging as they do to the natural history of humanity, are universal in nature. They are part of what it means to be a human body, however much any specific body may be culturally conditioned. It is on this material foundation that the most durable forms of human solidarity can be built."

In taking the specificity of human body as a point of departure, Eagleton is able to underscore an element which, though salient in Marx's materialist thought, was nonetheless left unamplified. One is tempted to read his updated version of materialism as a reconstruction of Marx's philosophical anthropology, but that would entail a blatant disregard of Eagleton's symphonic mind and enviable writerly skills which give the philosophic theme of materialism a new lease on life.

Department of Philosophy, University of Santo Tomas, Philippines

(C) 2017 Jovito V. Cariño

https://www.kritike.org/journal/issue 21/carino december2017.pdf

ISSN 1908-7330

(cc) BY-NC-ND 